\title{
SCHOOL CHAIR DESIGN AND KEY CRITERIA FROM THE USERS' POINT OF VIEW
}

\author{
Nataša RIZMAN HERGA ${ }^{1}$, Samo FOŠNARIČ ${ }^{2}$, Andreja KOLAR ${ }^{1}$ \\ ${ }^{1}$ Osnovna šola Ormož, Ormož, Slovenia \\ ${ }^{2}$ Univerza v Mariboru, Pedagoška fakulteta, Maribor, Slovenia \\ Corresponding author: \\ Nataša RIZMAN HERGA \\ Osnovna šola Ormož, Hardek 5, 2270 Ormož \\ Phone: +38641269056 \\ E-mail: natasa.rizman@osormoz.si
}

\section{ABSTRACT}

People are becoming increasingly sedentary, including students attending the upper level of primary education. Due to school, young people spend a lot of time sitting in class and at home, which has a negative effect on their health, especially if their work environment, including school furniture, does not meet all the criteria in terms of physiological, psychological, and sociological guidelines for healthy furniture design.

Chairs, as school furniture, have been designed according to standards that take into account ergonomic compliance with the body height of pupils. Slovenian classrooms are equipped with standard conventional chairs. In our student-oriented research, we were interested in whether chairs designed according to the standard are suitable for adolescents and what, if any, additional criteria must be met from the users' point of view.

The study included 192 upper level pupils (56.3\% girls and $43.7 \%$ boys), age of $12.4 \pm 1.7$ years. The research is based on quantitative and qualitative methodology. The descriptive causal non-experimental method was supported by the observation method.

The results of the survey show that older students (81.6\%) are of the opinion that they spend more time at school than at home. Due to prolonged sitting, older students $(55.3 \%)$ report problems more often than younger ones $(28.4 \%)$. Nearly two-thirds of younger students (63.8\%) also believe they sit more in school than at home. The results show that prolonged sitting negatively affects their health or general well-being. Differences between the responses of older and younger pupils are statistically significant both in the opinion expressed regarding the location of sitting $(p=0.010)$ and in the reporting of problems due to prolonged sitting $(p=0.001)$. There are no statistically 
significant differences between the sexes in both groups of older and younger pupils. Pupils sit on hard, uncomfortable, conventional chairs that are not tailored to their needs. They want to use comfortable, soft, swivel chairs with backrests and armrests. The study has shown that, in addition to comfort, school chairs must provide dynamic or active sitting. The present study confirms that static and rigidly shaped school chairs do not offer support for active and restless youth. Therefore, chair design must change to meet the physical, ergonomic, cognitive, and social needs of their users.

Keywords: school, pupil's view, types of chairs, sitting, health.

\section{OBLIKOVANJE ŠOLSKEGA STOLA IN KLJUČNI KRITERIJI Z VIDIKA UPORABNIKOV}

\section{POVZETEK}

Odrasli, mladostniki in otroci postajamo vse bolj sedeča populacija. Število sedečih vedenj na predmetni stopnji osnovnošolskega izobraževanja narašča. Mladostniki zaradi šole pri pouku in doma veliko časa presedijo kar negativno vpliva na njihovo zdravje, posebej če njihovo delovno okolje vključno s šolskim pohištvom ne zadosti vsem kriterijem glede na fiziološke, psihološke, sociološke smernice pri oblikovanju pohištva.

Stol kot del šolskega pohištva je oblikovan po standardih, ki upoštevajo ergonomsko skladnost s telesno višino učencev. Slovenske učilnice so opremljene s standardnimi konvencionalnimi stoli. V raziskavi osredotočeni na učenca nas je zanimalo ali je po standardu oblikovan stol primeren za mladostnike in katerim dodatnim kriterijem mora le ta zadostiti z vidika uporabnikov.

$V$ raziskavo je bilo zajetih 192 učencev predmetne stopnje (56,3\% deklet in 43,7 $\%$ fantov), s povprečno starostjo 12, $4 \pm 1,7$ leta. Raziskava temelji na kvantitativni in kvalitativni metodologiji. Deskriptivno kavzalno neeksperimentalno metodo smo podprli z metodo opazovanja.

Rezultati raziskave kažejo, da starejši učenci po njihovem mnenju (81,6\%) presedijo več časa v šoli kot doma. Zaradi dolgotrajnega sedenja poročajo o težavah pogosteje starejši učenci (55,3\%) kot mlajši (28,4\%), katerih 63,8\% meni, da več sedijo $v$ šoli kot doma, ki negativno vplivajo na njihovo zdravje oziroma splošno počutje. Razlike med odgovori starejših in mlajših učencev so statistično značilne tako pri izraženem mnenju glede lokacije sedenja $(p=0,010)$ kot pri poročanju težav zaradi dolgotrajnega sedenja $(p=0,001)$. Statistično značilnih razlik med spoloma tako pri starejših kot pri mlajših učencih ni. Učenci $v$ šoli sedijo na trdih, neudobnih konvencionalnih stolih, ki niso prilagojeni njihovim potrebam. Učenci so poročali, da želijo uporabljati udobne, mehke, vrtljive, stole z naslonjali za hrbet in roke. Razi- 
skava je pokazala, da mora šolski stol ob udobju zagotavljati tudi dinamično oziroma aktivno sedenje.

Pričujoča raziskava potrjuje, da statični in togo oblikovani šolski stoli ne nudijo podpore aktivnemu in nemirnemu mlademu človeku. Zato je pri oblikovanju je potrebno zadostiti fizičnim, ergonomskim, kognitivnim in socialnim vidikom njihovih uporabnikov.

Ključne besede: osnovna šola, učenčevo mnenje, vrste stolov, sedenje, zdravje.

\section{INTRODUCTION}

Promoting health in the school environment is especially important because health and education are inextricably linked. The health and safety of children are among the main priorities in schools as healthy children and adolescents are more likely to become healthy adults. Humans find sitting to be more comfortable and easier than standing, because in this position static load and energy consumption are lower, the position is more stable, and it does not require intensive strength in the lower limbs. Yet sitting is associated with or is the cause of many diseases (NIJZ, 2014). Humans are becoming increasingly sedentary. Children, adolescents, adults, and the elderly alike are subject to a more sedentary lifestyle. The environments in which we live increase the sedentary aspects of our lifestyles and reduce the active ones (Zupančič-Tisovec and Remec, 2017). Stamenkovič (2018) mentions the consequences of prolonged sitting, which are related to the musculoskeletal system: incorrect posture, weakened muscles, shoulder pain, neck stiffness, headaches, back and arm pain, lower back pain, achy shoulders, coccyx, and legs, dizziness, fatigue, etc. Prolonged sitting is detrimental to the whole organism. A sedentary lifestyle is a risk factor which has not received nearly enough attention.

Sitting also has a negative effect on the health of growing adolescents, who spend a lot of time sitting at school and later at home for schoolwork, and who spend their free time sitting in front of a computer and other screens. A lot of schoolwork is done in a sedentary position. First, they sit in school in class, then sitting continues at home while studying and carrying out school obligations. The first years of life are crucial for the health of the spine, especially during the time of accelerated and rapid growth (Attewell, 2003). Pupils spend about six hours of the day in school. They can only sit properly for the first three hours. After the third hour, mental and physical fatigue from the previous sitting begins (Stamenkovič, 2018). According to observations using the PEO method, students do $80 \%$ of schoolwork in class in a sitting position (Cardon et al., 2004). These hours and the further hours doing homework have a negative effect on adolescents' a) health, b) motor skills, and c) learning (their cognitive abilities and motivation itself) (Castelluci et al., 2010). Among the causes of incorrect or poor posture in children and adolescents are prolonged sitting, 
inadequate school furniture that is not in line with children's and adolescents' anthropometric measurements, physical inactivity, and, especially in young people, heavy school bags. Poor or "poorly formed" spines during school ages will cause problems in adulthood (Rosenbaum et al., 2007). Prolonged sitting affects the elasticity of the intervertebral muscles, resulting in greater pressure on the intervertebral discs, which in turn encourages their deformation and thus poses a greater risk of hernia (Hlebš and Mavsar, 2016). Pain in the lumbar spine occurs in adolescents who are taller. In many countries today's children differ from previous generations. In general, they are often taller, heavier and less fit. Adolescents undergoing their peak increase in height are at greater risk of low back pain. Many children (particularly girls) experience puberty earlier than those of previous generations, increasing the potential for musculoskeletal pain and disorders (Lueder and Berg Rice, 2008). During puberty, teenagers gain about $15 \%$ of their ultimate stature and $45 \%$ of their final skeletal mass (Spear, 2002). People who sit a lot have been shown to have a less healthy muscular system (Bilban and Repar, 2009). Prolonged sitting correlates with the occurrence of spinal deformities.

The goal of ergonomics is to improve the work environment to reduce injuries or pain. School furniture must have a modern ergonomic design and be specially adapted for various forms of schoolwork and in line with the physiological characteristics of children of a certain age (Fošnarič, 2001). Numerous studies have shown that there are discrepancies between the dimensions of school furniture and anthropometric measurements of students (Parcells et al., 1999, Panagiotopoulou et al., 2004, Domljan et al., 2008, Castelluci, 2010, Assiri et al., 2019). In Slovenia, too, there are discrepancies between the anthropometric dimensions of pupils and the dimensions of the chairs and tables used in classes (Šterlek and Fošnarič, 2008, Starman, 2009, Rizman Herga and Fošnarič, 2017, Rizman Herga, 2018).

Childhood is a critical time to learn and develop good postural habits that can be practiced throughout one's lifetime (Lueder and Berg Rice, 2008). The chair is one of the most anthropomorphic types of furniture. The function of the chair is to support the sitting body. The goal of ergonomics is to ensure that product design matches the physiological and psychological boundaries of the human body, so that products will ensure optimal performance. It is important for growing children to have a properly designed chair and desk, as this provides favourable conditions for the development of healthy posture. The school furniture used currently by young people in Slovenian schools is not always in line with standards. For each size class, the required product dimensions are also provided and these are important for ergonomic consistency with the user's body height. Experience and insight into Slovenian schools and research show inconsistency; students who utilize specialized classrooms such as science, technology, art, etc. are very heterogeneous in height, yet the classrooms are equipped with chairs (usually only one size per class) which, according to the standard, suit only a few of the students (Rizman, Herga, and Fošnarič, 2012, 2017). The construction, design, material and quality of chairs are not determined by the standard (Novak, 1995). Of course, school furniture is not the only cause of pain and discomfort. 
However, research has shown that awkward and constrained sitting postures and poorly designed classroom furniture are important contributors to children's musculoskeletal discomfort (Rizman, Herga, and Fošnarič, 2017). To reduce lower back pain, dynamic chairs are alternatives to the standard chair. Dynamic chairs force users into dynamic sitting, which is characterized by continuously changing posture (Kirn and Starc, 2014). Dynamically changing posture is beneficial for users because it periodically loads and unloads different musculoskeletal segments, which reduces overload and injury, and improves the health of cartilage.

The purpose of the research was to determine the pupils' perceptions of sitting, sitting in school, sensations after prolonged sitting, and to investigate the factors that ensure comfortable sitting from the point of view of the pupils. School chairs have changed little over time, compared to office chairs. We were interested in what a pupil-centred research approach would reveal.

\section{METHODOLOGY OF RESEARCH}

\section{Purpose of research and methodology}

The research is based on quantitative and qualitative methodology. Part of the data was obtained with a structured survey questionnaire (descriptive causal non-experimental method), and the qualitative part of the research was obtained with two different methods, observation and structured interview. The research is deductive as we tried to check the results of the questionnaire in the classroom.



Figure 1. Research model. 


\section{Participants}

The research included $192(\mathrm{~N}=192)$ pupils averaging age of 12.4 years of age; these pupils were drawn from Ormož Primary School. The research sample consisted of volunteer pupils. At the level of inferential statistics, the given cohort represents a simple non-probability sample drawn from a hypothetical population of primary school pupils.

Eight $(\mathrm{N}=8)$ pupils were included in the case study, of which half were younger (5th and 6th grade) and half older (8th or 9th grade), who had classes in the chosen classroom at the time of the experiment.

\section{Relevant sample characteristics}

As can be seen from Table 1, $60.4 \%$ of the sample were younger pupils -5 th, 6 th, and 7 th grade - and $39.6 \%$ were older pupils from the 8 th and 9 th grade of elementary school. There were more girls (56.3\%) than boys. Physically active pupils are those who exercise for at least 1 hour a day. $46.4 \%$ of the pupils fall into this category (Table $2)$. Other pupils (53.6\%) represent a group that exercises less than the time recommended by the World Health Organization.

Table 1. The number (f) and percentage (f\%) of pupils by gender.

\begin{tabular}{|l|c|c|c|}
\hline Gender and age & $\mathbf{f}$ & $\mathbf{f} \%$ & $\begin{array}{c}\text { Total } \\
(\mathbf{f}, \mathbf{f} \%)\end{array}$ \\
\cline { 1 - 3 } younger $\mathbf{M}$ & 58 & 50 & \multirow{2}{*}{$116,60.4$} \\
\hline younger $\mathbf{F}$ & 58 & 50 & \multirow{2}{*}{$76,39.6$} \\
\hline older M & 27 & 35.6 & \multirow{2}{*}{64.4} \\
\hline older F & 49 & & \\
\hline
\end{tabular}

Table 2. The number $(f)$ and percentage $(f \%)$ of pupils according to their physical activity.

\begin{tabular}{|l|c|c|}
\hline Daily activity & f & f \% \\
\hline Satisfactory & 89 & 46.4 \\
\hline Unsatisfactory & 103 & 53.6 \\
\hline Total & 192 & 100 \\
\hline
\end{tabular}




\section{Data collection procedure and instruments}

The data was collected through online questionnaires. The questionnaire was created using the free online survey tool 1KA. The data was collected in the period from November 2018 to December 2018. With the questionnaire we wanted to obtain answers to questions about sedentary behaviours of adolescents, focusing on sitting in school: how long adolescents sit before, during and after class, how they feel after sitting for a long time, how they assess the comfort of school chairs, and what seats or chairs they would like to use in class.

The online questionnaire was created in accordance with the purposes of the study. It consisted of open-ended and closed-ended questions. The reliability of the questionnaire was ensured by the exact nature of the questionnaire instructions, which we changed after the pilot study. The reliability of the questionnaire was determined by using Cronbach's reliability coefficient which confirmed the reliability of the instrument $(\alpha=0.705)$.

During observational case study (January 2019), we checked which chairs (among those offered and evaluated in the questionnaire) pupils actually used in class and how long they used particular chairs (time measurement). Pupils could change chairs during lessons or they could stand at a table. Pupils' activities were recorded (to monitor the sitting). After the experiment we used a structured interview to look for rationale and criteria for chair choices, and to determine how pupils felt while sitting, why they changed chairs, etc.

\section{Data Analysis}

The SPSS (Statistical Package for the Social Sciences) program was used in analysis at the level of descriptive and inferential statistics. Data analysis encompassed the application of a factor analysis and Cronbach's alpha coefficient $(\alpha)$ for the analysis of metric characteristics. The Chi-square test was used for the analysis of differences between the two groups by gender, age (younger, older) and physical activity (sufficient, insufficient). The Mann-Whitney test was used to analyse differences between genders in ranking chair assessments. We also used tabular and graphical presentations of absolute (f) and percentage ( $\mathrm{f} \%$ ) frequencies.

\section{RESULTS}

The results with the interpretation will be presented in two parts. Initially, we discuss sitting in school, then focus on school chairs and the pupils' work environment. 


\section{Adolescent sitting}

Table 3 shows the opinions of adolescents regarding sitting at home and at school, namely their opinion on where they spend more time in a sitting position. Older pupils $(81.6 \%)$ believe that they spend more time sitting at school than at home. Almost two thirds of younger pupils $(63.8 \%)$ share that opinion. The difference in responses between pupils by age is statistically significant $(\chi 2=9.121 ; \mathrm{p}=0.010)$, but not by gender $(\chi 2=3.721 ; \mathrm{p}=0.156)$. Three-quarters of girls $(73.1 \%)$ and $66.7 \%$ of boys believe they spend more time sitting at school.

Table 3. The location where pupils believe they sit most, by gender and age.

\begin{tabular}{|c|c|c|c|c|c|c|}
\hline & & ANSWER & HOME & SCHOOL & $x^{2}$ & $\mathbf{p}$ \\
\hline \multirow{4}{*}{ 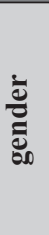 } & \multirow{2}{*}{ male } & $\mathrm{f}$ & 28 & 56 & \multirow{4}{*}{3.721} & \multirow{4}{*}{0.156} \\
\hline & & $f \%$ & 33.3 & 66.7 & & \\
\hline & \multirow{2}{*}{ female } & $\mathrm{f}$ & 29 & 79 & & \\
\hline & & $f \%$ & 26.9 & 73.1 & & \\
\hline \multirow{4}{*}{ : } & \multirow{2}{*}{ younger } & $\mathrm{f}$ & 42 & 74 & \multirow{4}{*}{9.121} & \multirow{4}{*}{0.010} \\
\hline & & $\mathrm{f} \%$ & 36.2 & 63.8 & & \\
\hline & \multirow{2}{*}{ older } & $\mathrm{f}$ & 14 & 62 & & \\
\hline & & $f \%$ & 18.4 & 81.6 & & \\
\hline
\end{tabular}

Table 4 shows the answers to the question of whether the pupils experience any problems due to excessive sitting at school. Thirty-seven percent of all surveyed pupils stated that they have occasional problems due to prolonged sitting. We did not detect a statistically significant difference between boys (70.2 \% without problems) and girls ( $53.7 \%$ without problems). However, there is a statistically significant difference $(\chi 2=$ $14.005 ; \mathrm{p}=0.001)$ between younger and older pupils. Older pupils have more problems due to prolonged sitting (55.3\% of pupils with difficulties or occasionally difficulties) than younger pupils (28.4\% of pupils with difficulties).

Table 5 shows how adolescents feel and what problems they have after prolonged sitting at school. More than half of pupils feel the need to stretch $(59 \%)$, more than half $(55 \%)$ feel tired and sleepy, and they often mentioned that they feel uncomfortable (29 $\%)$. Responses listing pain in different parts of the body are also common. Many pupils reported pain in the ischial tuberosity (commonly referred to as sitting bones) (31\%), lower back pain $(22 \%)$, and neck pain $(21 \%)$. Only 28 pupils $(15 \%)$ feel fine after sitting for a long time. 
Table 4. Adolescents' problems due to prolonged sitting at school, by gender and age.

\begin{tabular}{|c|c|c|c|c|c|c|c|}
\hline & & ANSWER & YES & NO & OCCASIONALLY & $\chi^{2}$ & $\mathbf{p}$ \\
\hline \multirow{4}{*}{ 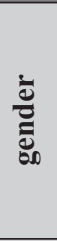 } & \multirow{2}{*}{ male } & $\mathrm{f}$ & 3 & 59 & 22 & \multirow{4}{*}{5.490} & \multirow{4}{*}{0.064} \\
\hline & & $f \%$ & 3.6 & 70.2 & 26.2 & & \\
\hline & \multirow{2}{*}{ female } & $\mathrm{f}$ & 5 & 58 & 45 & & \\
\hline & & $f \%$ & 4.6 & 53.7 & 41.7 & & \\
\hline \multirow{4}{*}{$\underset{\sigma}{\infty}$} & \multirow{2}{*}{ younger } & $\mathrm{f}$ & 4 & 83 & 29 & \multirow{4}{*}{14.005} & \multirow{4}{*}{0.001} \\
\hline & & f\% & 3.4 & 71.6 & 25 & & \\
\hline & \multirow{2}{*}{ older } & $\mathrm{f}$ & 4 & 34 & 38 & & \\
\hline & & $f \%$ & 5.3 & 44.7 & 50 & & \\
\hline
\end{tabular}

Table 5. Number (f) and structural percentages ( $f \%$ ) of adolescents' problems after prolonged sitting at school.

\begin{tabular}{|l|c|c|}
\hline Condition/problem & f & f \% \\
\hline Unpleasant. & 54 & 29 \\
\hline I feel sleepy and tired. & 103 & 55 \\
\hline I feel the need to stretch. & 110 & 59 \\
\hline Fine. & 28 & 15 \\
\hline I have neck pain. & 39 & 21 \\
\hline I have lower back pain. & 41 & 22 \\
\hline I have upper back pain. & 28 & 15 \\
\hline I have a headache. & 29 & 15 \\
\hline My shoulders hurt. & 17 & 9 \\
\hline My buttocks (sitting bones) hurts. & 58 & 31 \\
\hline I feel pain between my shoulder blades. & 17 & 9 \\
\hline Other. & 17 & 9 \\
\hline
\end{tabular}




\section{School chairs}

The surveyed pupils gave many interesting, different, and original answers to the open-ended question of what chair they would use in school for classes. Similar descriptions were grouped into the same category. Table 6 shows that comfort comes first, followed by comfort with dynamic seating, and comfort with functionality. From the answers, we can conclude that the pupils want seats that would be first and foremost comfortable, but at the same time functional and allow for dynamic sitting.

Table 6. Number (f) of descriptions of the chair pupils would like to have in class.

\begin{tabular}{|c|c|c|c|}
\hline & Description & f & $\begin{array}{l}\text { TOTAL } \\
\text { f (f \% \%) }\end{array}$ \\
\hline \multirow{5}{*}{ COMFORT } & comfortable & 57 & \multirow{5}{*}{$214(63.9 \%)$} \\
\hline & soft & 105 & \\
\hline & heated & 42 & \\
\hline & padded & 3 & \\
\hline & massage chair & 7 & \\
\hline \multirow{4}{*}{$\begin{array}{l}\text { COMFORT } \\
\text { FUNCTIONALITY }\end{array}$} & computer chair & 14 & \multirow{4}{*}{$40(11.9 \%)$} \\
\hline & office chair & 8 & \\
\hline & adjustable & 9 & \\
\hline & with armrests & 9 & \\
\hline \multirow{4}{*}{$\begin{array}{l}\text { COMFORT } \\
\text { DYNAMIC SITTING }\end{array}$} & swivel chair & 15 & \multirow{4}{*}{$41(12.2 \%)$} \\
\hline & flexible & 4 & \\
\hline & computer chair & 14 & \\
\hline & office chair & 8 & \\
\hline \multirow{3}{*}{ MATERIAL } & wood & 6 & \multirow{3}{*}{$12(3.6 \%)$} \\
\hline & fabric & 3 & \\
\hline & leather & 3 & \\
\hline \multirow{3}{*}{ OTHER } & large & 17 & \multirow{3}{*}{$28(8.4 \%)$} \\
\hline & ordinary & 6 & \\
\hline & modern, colourful, good & 5 & \\
\hline
\end{tabular}



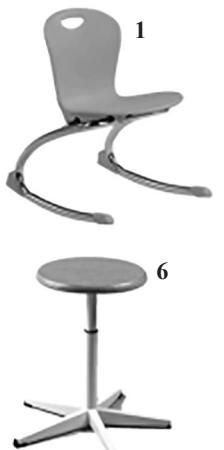

$\bullet$
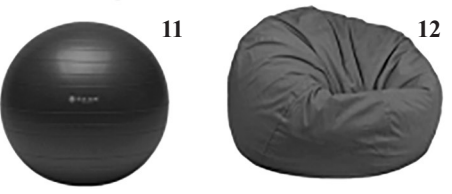
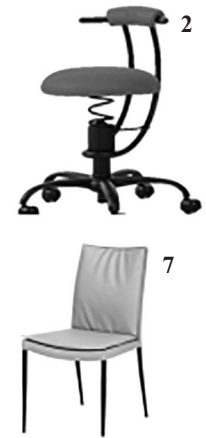

.

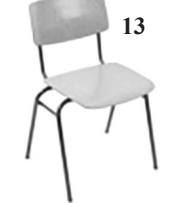

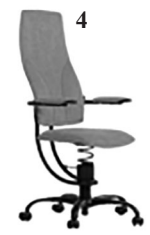
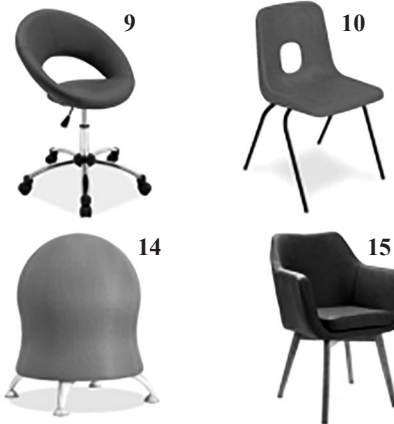

Figure 1:Different types of chairs used in the study.

Table 7 shows how pupils rated the school chairs they use in class. The results $($ Mean $=2.427$ ) show that the chairs are on the border between uncomfortable and moderately comfortable. When asked if they would like a padded, soft seat, $181(94.3 \%)$ answered affirmatively (Table 8).

Table 7. Rating of school chairs.

\begin{tabular}{|c|c|c|c|c|c|c|c|}
\hline $\begin{array}{l}\text { Number } \\
\text { Rating }\end{array}$ & 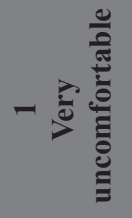 & 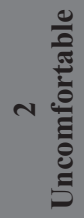 & 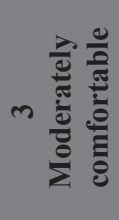 & 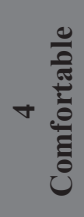 & 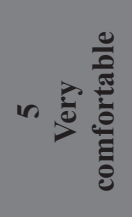 & $\overline{\mathrm{X}}$ & SD \\
\hline $\mathbf{N}$ & 29 & 73 & 75 & 9 & 6 & \multirow{2}{*}{2.427} & \multirow{2}{*}{0.912} \\
\hline f \% & 15.1 & 38 & 39.1 & 4.7 & 3.1 & & \\
\hline
\end{tabular}


Table 8. The number (f) and structural percentage (f\%) for soft chairs.

\begin{tabular}{|l|c|c|}
\hline $\begin{array}{l}\text { Would you like to sit on an } \\
\text { upholstered chair? }\end{array}$ & f & f \% \\
\hline Yes & 181 & 94.3 \\
\hline No & 11 & 5.7 \\
\hline
\end{tabular}

Figure 2 shows the results of asking pupils to choose from 15 different seats (Figure 1). Pupils selected a) the seat they liked and b) the seat they would use in class. The figure shows that pupils would use seats $3,4,12$, and 15 . There are no major differences between the seats they like and those they would actually use in class, except for seat number 12 (bean bag chair). Pupils like the bean bag chair the most, but it was chosen by far fewer pupils for use in class.

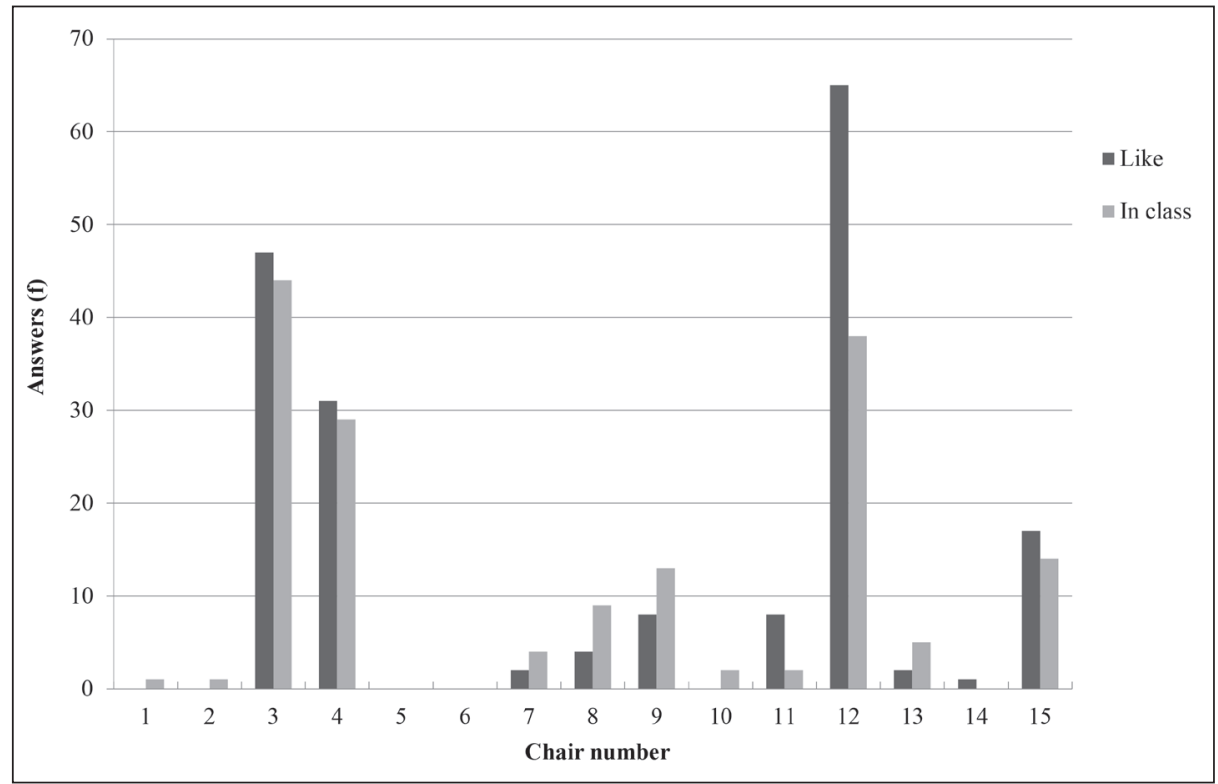

Figure 2. Chairs by likeability and use in class.

Table 9 shows the number and the structural shares of the chairs that pupils chose to use in class. The legend below the table explains what a specific seat allows or what properties it has. Most pupils $(27 \%)$ would use seat number 3 in classes. This is followed by seats 12 and 4 . 
Nataša RIZMAN HERGA, Samo FOŠNARIČ, Andreja KOLAR: SCHOOL CHAIR DESIGN AND KEY CRITERIA ..., 43-61

Table 9. Number (f) and structural percentages ( $f \%$ of seats selected for class.

\begin{tabular}{|l|c|c|c|c|c|c|c|c|c|c|c|c|c|c|c|}
\hline Chair & $\mathbf{1}$ & $\mathbf{2}$ & $\mathbf{3}$ & $\mathbf{4}$ & $\mathbf{5}$ & $\mathbf{6}$ & $\mathbf{7}$ & $\mathbf{8}$ & $\mathbf{9}$ & $\mathbf{1 0}$ & $\mathbf{1 1}$ & $\mathbf{1 2}$ & $\mathbf{1 3}$ & $\mathbf{1 4}$ & $\mathbf{1 5}$ \\
\hline Feature & 1, & 1, & 1, & 1, & 3, & 4 & 1, & 1, & 1, & 1 & 3, & 3 & 1 & 3, & 1, \\
& 4 & 3, & 2, & 2, & 4 & & 3 & 3, & 3, & & 4 & & & 4 & 2, \\
& & 4 & $\begin{array}{r}3, \\
4\end{array}$ & 4 & & & & 4 & 4 & & & & & & 3 \\
\hline f & 1 & 1 & 44 & 29 & 0 & 0 & 4 & 9 & 13 & 2 & 2 & 38 & 5 & 0 & 14 \\
\hline $\mathbf{f} \%$ & 1 & 1 & 27 & 18 & 0 & 0 & 2 & 6 & 8 & 1 & 1 & 23 & 3 & 0 & 9 \\
\hline
\end{tabular}

1. Back support

2. Armrest

3. Padding

4. Dynamic sitting

During the observation, we measured how long the pupils sat in each chair during class. Table 10 shows that they spent most time on chair 3 . This is the chair that was most often chosen as the chair that pupils would like to use in class. After chair 3, pupils spent the most time in chairs 1 and 11 .

Table 10. Sitting time per chair in class.

\begin{tabular}{|l|c|c|c|c|c|c|c|}
\hline Chair & $\mathbf{1}$ & $\mathbf{3}$ & $\mathbf{6}$ & $\mathbf{7}$ & $\mathbf{1 1}$ & $\mathbf{1 2}$ & $\mathbf{1 3}$ \\
\hline Time (s) & 3235 & 8935 & 901 & 674 & 3186 & 1332 & 0 \\
\hline
\end{tabular}

Figure 3 shows the structural proportions of pupils' responses regarding the choice of seat in class and the structural proportions of time spent in the chair during class monitoring. The figure shows that the results of the survey and the results of the experiment differ regarding the chairs offered. Pupils spent the most time in seats 3 , 1 , and 11 during the experiment. 


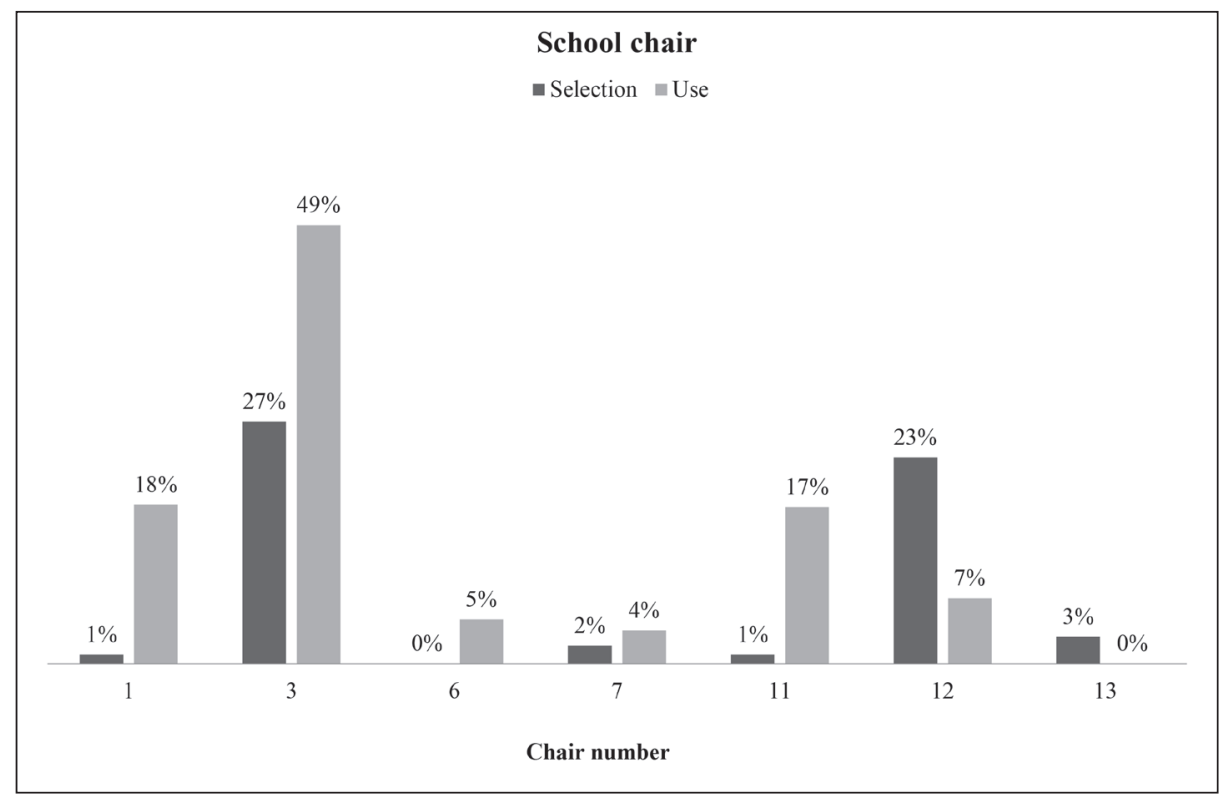

Figure 3. Selection and actual use of the chair.

\section{DISCUSSION}

Sedentary behaviours are on the rise in adolescents as well. The results of the research showed that there are differences of opinion between younger and older pupils. Most of the older pupils are of the opinion that they sit more in school than in their free time. However, more than a third of younger pupils think that they spend more time sitting in their free time. The difference between younger and older pupils is statistically significant, while the results in the answers between boys and girls do not differ statistically $\left(\chi^{2}=3.721 ; \mathrm{p}=0.156\right)$. Pupils sit while waiting for classes, during snack and lunch periods, and most of all during the compulsory classes, which are supplemented at the upper level with additional lessons for gifted pupils and for pupils with learning disabilities, elective subjects, etc. Sitting time at school is also extended due to the curriculum and obligations of older pupils. Prolonged sitting in class makes adolescents feel unwell; they need to stretch, they feel sleepy, they are tired, they have sore buttocks and back pain. More than a third of the surveyed pupils experience the previously described problems due to prolonged sitting. Frequent muscle fatigue and pain are the result of prolonged static sitting (Ninčević and Bilban, 2010). There is no statistically significant difference between genders in frequency of adolescent problems due to prolonged sitting at school. The difference in the frequency of problems between different age groups of the pupils is statistically significant 
$\left(\chi^{2}=14.005 ; \mathrm{p}=0.001\right)$. Older pupils have more problems due to prolonged sitting at school than younger pupils.

The objective of the second part of the research was to determine how customized and suitable the school chairs are as part of the student work environment. The school chairs they use were rated "uncomfortable" with an average of 2.427 (SD = 0.912). The current chairs they use in class are wooden conventional chairs; an absolute majority of pupils think they are too hard, uncomfortable, unpleasant, and poorly fitted to their anthropometric measures, which in the long run has a negative impact on all aspects of life and work at school and on the health of pupils.

An overview of characteristics of the chair that pupils would like to use in class gave a range of different descriptive answers, which we combined into groups by their meaning. The analysis showed that pupils would primarily like comfortable chairs. This was also confirmed by the answers to the question of whether they would like a padded chair, where the majority of pupils (94.3\%) answered affirmatively. In addition to the comfort provided by a soft, padded, and comfortable chair, pupils would also like chairs that are functional and height-adjustable, with backrests and armrests, and which allow movement described with the words "swivel", "movable", and "mobile". Chairs meeting these criteria would allow pupils to sit dynamically. A study comparing dynamic and static sitting concludes that sitting on a dynamic chair has a significant effect on torso kinematics (Van Dieën, Hermans, 2001).

In the survey, adolescents could choose from 15 different seats that had different characteristics: back support, armrests, padding, dynamic seating options, or combinations of these options. We first asked them which seat they liked, and in the second part, pupils were asked which of the offered chairs they would use at school in class (Appendix 1). Seats 3, 4, 12, and 15 were the most popular. All of them are soft, padded and provide support for the back, three have armrests, and two also allow movement - dynamic sitting. For class, pupils would choose chairs that offer comfort, support, and allow dynamic sitting. Chair number 12, the bean bag chair, was the exception; it is the most popular among pupils because it provides them with comfort, but fewer than half of the pupils who like it best would actually choose to use it in class. In class, most pupils would use chair 3 (a modern, adjustable office chair), followed by the bean bag chair and a "Spinalis" chair, which allows dynamic sitting.

The results of the survey were verified by an observational case study. In the classroom where the experiment took place, different seats were installed (numbered $1,3,6,7,11,12$, and 13 in the survey). Pupils involved in the experiment could change seats during class. The results measuring the time spent in each seat showed that during class the pupils spent the most time in chair 3. This is followed by a chair with armrests and a backrest that allows rocking (number 1) and an exercise ball (number 11). All of these seats allow rocking, leaning, bouncing - movements that are becoming ever more rare, especially in the phase of growing up. Unfortunately, in the absence of new findings, the basic starting points and guidelines for chair design are still international standards and static anthropometry (Parcells et al., Castellucci et al., 2010, Domljan, 2010). 
An analysis of the structured interview after the experiment showed that the exercise ball was most often the first choice of the pupils. The reasons for the first choice were varied; the pupils stated that they liked it, it is interesting, it has beautiful colours, it allows rocking or even bouncing. As a disadvantage they stated that sitting on the ball made them restless and that it was difficult to take notes so they moved to a different chair. Research has shown that sitting on an exercise ball has some characteristics of walking or standing and therefore occasionally replacing ordinary chairs with exercise balls is recommended (Kirn and Starc, 2014). When asked why they spent the most time sitting in chair 3, respondents answered that the chair is of suitable height and soft, has armrests and back support, it allowed them to swivel and was in their opinion the best chair (among those offered). To put it in their words, pupils would like to have chairs like office employees have. By analysing the results of the observation sheets we found that in the selected seats the pupils sat dynamically by rocking, swivelling left-right, moving backward and forward, and bouncing; there was limited static sitting. The pupils involved in the experiment were rarely still; they changed sitting positions. The analysis of the experiment showed that younger pupils changed seats more often than older pupils. The results coincide with a study on pupils' working postures in primary school classrooms in Croatia (Domljan et al., 2010), which also found that pupils sought comfort by changing their sitting position and that older pupils sat more still than younger pupils.

\section{CONCLUSIONS}

This paper illustrates the needs of the school workspace from the pupils' perspective. Chairs are a vital part of their work environment, especially for older pupils, who spend more time in sedentary position. Due to prolonged sitting at school, pupils feel uncomfortable, report various back pains and describe problems with how they are feeling (drowsiness, fatigue, malaise). The results of the research confirmed the assumptions that pupils feel unwell when sitting at school on conventional chairs. Studies in Slovenia have shown that there are discrepancies between the dimensions of school furniture and the anthropometric dimensions of pupils who use that furniture. However, compliance with size classes according to the prescribed standards for school furniture should not be the only criterion. The results of the research confirmed the assumptions that pupils feel unwell when sitting in class on conventional chairs. In terms of which properties pupils believe school chairs should have, we found that they want chairs that are comfortable, soft, with back support, armrests, and are adjustable in inclinations and height and allow dynamic sitting, which was shown by case study through observation. Pupils need chairs that allow them to rock, swing, turn, and bend in all directions. The results of this study support the existing knowledge that dynamic sitting is better and healthier than static sitting. Conventional school chairs are less appropriate for long-term use. School chairs should promote 
sitting dynamics that suit the physiological, psychological, sociological, cognitive, and ergonomic aspects of their users.

Based on the above, in order to improve the working environment for pupils by tailoring it to them, we suggest that classrooms be equipped with chairs that allow dynamic sitting, and that they also have chairs that allow active sitting (balls). Classrooms should be equipped with different types of dynamically and ergonomically designed chairs. It is also necessary to change the pedagogical process itself, so that it allows changing the seating order during class, standing classes, taking walks, etc., with active breaks, a short time for health, active learning, and teaching with research and experience, adapting lessons and the learning environment to the pupils, which does not require large financial investment, but reduces the sedentary way of learning and teaching.

For the health of our children, it is necessary to follow the progress of school furniture improvements, provide ergonomically equipped classrooms, and strive to reduce static sitting as much as possible or replace it entirely with dynamic or active sitting - with a single goal: the improved growth and overall development of healthy adolescents.

\section{REFERENCES}

Assiri, A., Mahfouz, A. A., Awadalla, N. J., Abouelyazid, Y. A., Shalaby, M., Abogamal, A., ... Riaz, F. (2019). Classroom furniture mismatch and back pain among adolescent schoolchildren in Abha City, Southwestern Saudi Arabia. International Journal of Environmental Research and Public Health, 16(8), 1-9. https://doi.org/10.3390/ ijerph16081395.

Attewell, P., Battle, J., \& Suazo-Garcia, B. (2003). Computers and young children: Social benefit or social problem? Social forces, 82(1), 277-296. https://doi.org/10.1353/ sof.2003.0075.

Bilban, M., \& Repar, A. (2009). Problemi sedečih delovnih mest [Problem of sedentary workplace]. Delo in varnost, 54(6), 42-52. Retrieved from http://www.dlib.si/stream/ URN:NBN:SI:DOC-CEULEEGU/b9fb4164-9ad6-490e-9b15-448d601d0d0f/PDF.

Cardon, G., De Clercq, D., De Bourdeaudhuij, I., \& Breithecker, D. (2004). Sitting habits in elementary schoolchildren: a traditional versus a »Moving school«. Patient Education and Counseling, 54(2), 133 - 142. https://doi.org/10.1016/S0738-3991(03)00215-5.

Castellucci, H. I., Arezes, P. M., \& Viviani, C. A. (2010). Mismatch between classroom furniture and anthropometric measure in Chilean schools. Applied Ergonomics, 41 (4), 563 - 568. https://doi.org/10.1016/j.apergo.2009.12.001.

Domljan, D., Grbac, I., \& Hadina, J. (2008). Classroom furniture design - correlation of pupil and chair dimensions. Collegium Antropologicum, 32(1), 257-265. Retrieved from https://hrcak.srce.hr/file/37403.

Domljan, D., Grbac, I., \& Vlaović, Z. (2010). Pupils' working postures in primary school classrooms. Periodicum biologorum, 112(1), 39-45. Retrieved from https://hrcak.srce. $\mathrm{hr} / 52690$. 
Fošnarič, S. (2001). Učenci in šolsko delovno okolje [Pupils and the school environment]. Maribor: Pedagoška fakulteta Maribor.

Hlebš, S., \& Mavsar, J. (2016). Kakšen je najboljši položaj sedenja za hrbtenico po mnenju slovenskih fizioterapevtov [What do Slovenian physiotherapists consider to be the best spinal sitting posture]. Fizioterapija, 24(1), 15-24. Retrieved from https:// physio.si/wp-content/uploads/2016/11/3.Kaks\%CC\%8Cen-je-najboljs\%CC\%8Ci-poloz\%CC\%8Caj-sedenja-za-hrbtenico-po-mnenju-slovenskih-fizioterapevtov-p15-24-.pdf.

Kirn, B., \& Starc, V. (2014). Frequency analyses of postural sway during prolonged sitting on a large gymnastics ball and stool. American Journal of Sports Science and Medicine, 2(1), 17-20. Retrieved from http://www.sciepub.com/portal/downloads?doi=10.12691/ ajssm-2-1-3\&filename=ajssm-2-1-3.pdf.

Lueder, R., \& Berg Rice, V. J. (2008). Ergonomics for children: designing products and places for toddlers to teens. New York: Taylor \& Francis.

Nacionalni inštitut za javno zdravje. (2014). Promocija zdravja v šoli: dokazi za učinkovito ukrepanje. Retrieved from https://www.nijz.si/sl/slovenska-mreza-zdravih-sol.

Ninčević, A., \& Bilban, M. (2010). Empirična raziskava problematike dolgotrajnega sedečega dela pri uporabi osebnega računlanika [Empirical research of the problems occurring by lasting sitting work using personal computer]. Delo in varnost, 55(1), 40-52. Retrieved from http://www.dlib.si/stream/URN:NBN:SI:doc-DYJKH5LL/b9328dd7-cc82-4352-8ee3-5ba9cea1693a/PDF.

Novak, H., Žagar, D., Strel, J., Štihec, J., Pisanki, M., \& Juričič, M. (1995). Obremenitve osnovnošolcev: posledice in vzroki. [Burdens on primary school children: consequences and causes.] Radovljica: Didakta.

Panagiotopoulou, G., Christoulas, K., Papanckolaou, A., \& Mandroukas, K. (2004). Classroom furniture dimensions and anthropometric measures in primary school. Applied Ergonomics, 35(2), 121 - 128. https://doi.org/10.1016/j.apergo.2003.11.002.

Parcells, C., Stommel, M., \& Hubbard, R. P. (1999). Mismatch of classroom furniture and student body dimensions. Journal of Adolescent Health, 24(4), 265-273. https://doi. org/10.1016/s1054-139x(98)00113-x.

Rizman Herga, N., \& Fošnarič, S. (2012). Dimenzijsko-antropometrijska analiza šolskega interierja $\mathrm{v}$ obdobju adolescence [Dimensional-anthropometric analysis of the school interior in early adolescence]. Pedagoška obzorja: časopis za didaktiko in metodiko, 27(5), 123-137. Retrieved from http://www.pedagoska-obzorja.si/Revija/Vsebine/PDF/ DSPO_2012_27_03.pdf.

Rizman Herga, N., \& Fošnarič, S. (2017). Coordination of school science classroom furnishings with anthropometric parameters for 11-12 year-old children. Revija za Elementarno izobraževanje, 10(1), 99-113. Retrieved from https://journals.um.si/index. $\mathrm{php} / \mathrm{education/article/view/335.}$

Rizman Herga, T. (2018). Ustreznost šolskih miz in stolov glede na antropometrične značilnosti dijakov Gimnazije Ormož. [Suitability of school desks and chairs according to the anthropometric characteristics of students of the Gymnasium Ormož.] Ormož: Gimnazija Ormož.

Rosenbaum, P., Paneth, N., Leviton, A., Goldstein, M., Bax, M., Damino, D., \& Jacobsson, B. (2007). A report: the definition and classification of cerebral palsy April 2006. Developmental medicine and child neurology, 49(s109), 8-14. https://doi. org/10.1111/j.1469-8749.2007.tb12610.x. 
Spear, B. A. (2002). Adolescent growth and development. Journal of the American Dietetic Association, 102 (3), 23-29.

Stamenkovič, R. (2018). Ali je sedenje res tako nevarno? Priročnik za pravilno držo. [Is sitting really that dangerous? A guide to proper posture.] Maribor: Založba Chiara.

Starman, L. (2009). Analiza ustreznosti izmer šolskih stolov glede na antropometrične značilnosti učencev v osnovnih šolah [Adequacy analysis of school chair measurements according to the anthropometric characteristics of primary school pupils]. Kranj: Fakulteta za organizacijske vede.

Šterlek, A., \& Fošnarič, S. (2008). Obremenjenost učencev zaradi neprimernega šolskega pohištva v prvem vzgojno-izobraževalnem obdobju osnovne šole [Overburdening of pupils with inappropriate classroom furniture in the first triad of elementary school]. Revija za elementarno izobraževanje, 1(1/2), 15-24. Retrieved from https://journals.um.si/ index.php/education/article/view/190.

Van Dieën, J. H., de Looze, M. P., \& Hermans, V. (2001). Effects of dynamic office chair on trunk kinematics, trunk extensor EMG and spinal shrinkage. Ergonomics, 44(7), 739750. https://doi.org/10.1080/00140130120297. 